\title{
Geographic variability in form, size and survival of Egregia menziesii around Point Conception, California
}

\author{
C. A. Blanchette ${ }^{1,2, *}$, B. G. Miner ${ }^{1,2,3}$, S. D. Gaines ${ }^{1,2}$ \\ ${ }^{1}$ Marine Science Institute, and ${ }^{2}$ Department of Ecology, Evolution and Marine Biology, University of California Santa Barbara, \\ Santa Barbara, California 93106, USA \\ ${ }^{3}$ Department of Zoology, University of Florida, Gainesville, Florida 32611, USA
}

\begin{abstract}
Intra-specific morphological variability is common among many species of plants, and is particularly common among marine algae. Populations of the kelp Egregia menziesii (Turner) Areschoug are known to be extremely variable in form, and variability in this species is well-correlated with geographical distribution. Populations north of Point Conception, California, are characterized by individuals having thick, tough, wide stipes and small blades, whereas populations south of Point Conception are characterized by individuals having thin, smooth stipes and large blades. Point Conception (hereafter PC) is a well-known biogeographic boundary for many marine species. The region north of PC is typified by cold, nutrient-rich water favorable to plant growth, but also by high wave exposure, increasing the likelihood of plant breakage or dislodgement. The region south of PC is characterized by warmer, oligotrophic water (less favorable for plant growth), but the potential for plant breakage or dislodgment is low due to the calm seas in this region. Using reciprocal transplant experiments, we examined the potential adaptive value of the morphologies of both populations (northern and southern) in the light of these physical gradients among sites north and south of PC, and the tradeoff between rapid growth and increased risk of breakage. We reciprocally transplanted northern- and southern-form E. menziesii among several sites north and south of PC and monitored size and survival of each individual over a 5 mo period. In general, both survival and growth of the northern form was greatest at the northern sites, and southern form survival and growth was greatest at the southern sites. Overall, growth was greatest at the northern sites, and the greatest increase in size was achieved by a southern-form individual at a northern site. These results indicate that regionally specific morphological forms of $E$. menziesii seem to be uniquely adapted to maximize growth and survival under conditions typical of their native region. However, in the absence of breakage, southern-form E. menziesii have the potential to grow large under northern conditions. Northern-form $E$. menziesii have a reduced probability of breakage or dislodgment due to their high-strength, low-drag morphology. Southern-form E. menziesii have much lower breaking strengths and higher drag than northern forms, but have a higher surface area per unit of stipe, potentially advantageous for nutrient uptake in the low-nutrient environment south of Point Conception. Although these morphological forms appear to be advantageous within each of these regions, it remains to be explored whether their morphology can be altered at an early life stage or whether it is genetically fixed.
\end{abstract}

KEY WORDS: Egregia menziesii $\cdot$ Algal growth $\cdot$ Breakage $\cdot$ Kelp $\cdot$ Nutrients $\cdot$ Point Conception

Resale or republication not permitted without written consent of the publisher

\section{INTRODUCTION}

Botanists have long recognized that individuals of a species grown in different habitats may exhibit alternative forms. Such morphological differences among habitats may confer selective advantages to individuals inhabiting physically different environments. For example, many species of trees to exhibit strikingly different growth forms as a function of wind stress, altitude and light intensity (Jaffe 1973, Harper 1977, 
Holbrook \& Putz 1989, Niklas 1995). Intraspecific morphological variability may be common in species inhabiting physically variable environments, especially if dispersal distances are relatively limited, and gene flow between environments is low (Slatkin 1987).

The combination of variable physical environments and limited dispersal is a common characteristic of many species of marine macrophytes. Marine algal species typically occupy broad geographic ranges (Pielou 1978, Gaines \& Lubchenco 1982), and within these ranges may inhabit a wide variety of habitats ranging from intertidal to subtidal, and from waveexposed open-coast sites to sheltered bays. The dispersal capabilities of many seaweeds, particularly kelps, are thought to be relatively limited (Anderson \& North 1966, Dayton 1973, Kopczak et al. 1991, but see Reed et al. 1988), with very restricted gene flow in some species (Coyer et al. 1997). Intraspecific differences in morphology (Chapman 1974), temperature tolerance (Gerard \& DuBois 1988), photoadaptive responses (Gerard 1988), and responses to nitrogen availability (Gagne et al. 1982, Espinoza \& Chapman 1983) have all been reported to be the result of genetic and/or phenotypic variability among geographically isolated populations. Phenotypic plasticity is generally common among marine algae and is thought to allow plants to adapt rapidly to changing conditions (Gerard \& Mann 1979, Norton et al. 1981, Druehl et al. 1989, Norton 1991, Dudgeon et al. 1995, Kubler \& Dudgeon 1996, Blanchette 1997).

Intra-specific morphological variability is strikingly apparent among populations of the brown alga Egregia menziesii. E. menziesii is a perennial kelp (order Laminariales, family Alariaceae) that occurs along moderately wave-swept, intertidal and subtidal (to $20 \mathrm{~m}$ ) habitats of the Eastern Pacific coast from Alaska to Baja California (Abbott \& Hollenberg 1976). An individual can grow up to $15 \mathrm{~m}$ long and typically consists of a single main stipe (known as the rachis), which may be highly branched or unbranched. The rachis is lined with small blades 2 to $8 \mathrm{~cm}$ long on either side, and in some cases with buoyant pneumatocysts. The appearance of mature E. menziesii lined with short blades along the main stipe makes it obvious why it is commonly known as 'the feather boa kelp'. Morphological variability in this species is approximately correlated with geographical distribution; northern populations (Alaska to Cape Mendocino) have tuberculate stipes and smooth sporophylls; southern populations (Los Angeles to Baja California) have smooth stipes and wrinkled sporophylls; populations from the middle coast (the Channel Islands and from the vicinity of Cape Mendocino to Ventura County) possess a combination of features observed in the geographic extremes and include a few unique vegetative and reproductive morpholo- gies as well (Abbott \& Hollenberg 1976). Although natural populations of this brown alga are extremely diverse morphologically, the degree to which this morphological variability is correlated with environmental conditions is unknown (Silva 1957, Chapman 1962).

Given the great degree of morphological variability in the genus Egregia, the taxonomic status of species in the genus has been recently debated. Silva (1957) described 2 species of Egregia occurring along the west coast of North America: E. menziesii (Turner) Areschoug (1876) ranging from Vancouver Island, British Columbia, Canada to Point Conception (hereafter PC), California, and E. laevigata Setchell (1896) ranging from PC to Baja California, Mexico. These 2 species overlapped in the region of the Channel Islands (Silva 1957). Hollenberg \& Nicholson (1969) described the distribution of E. laevigata as being from

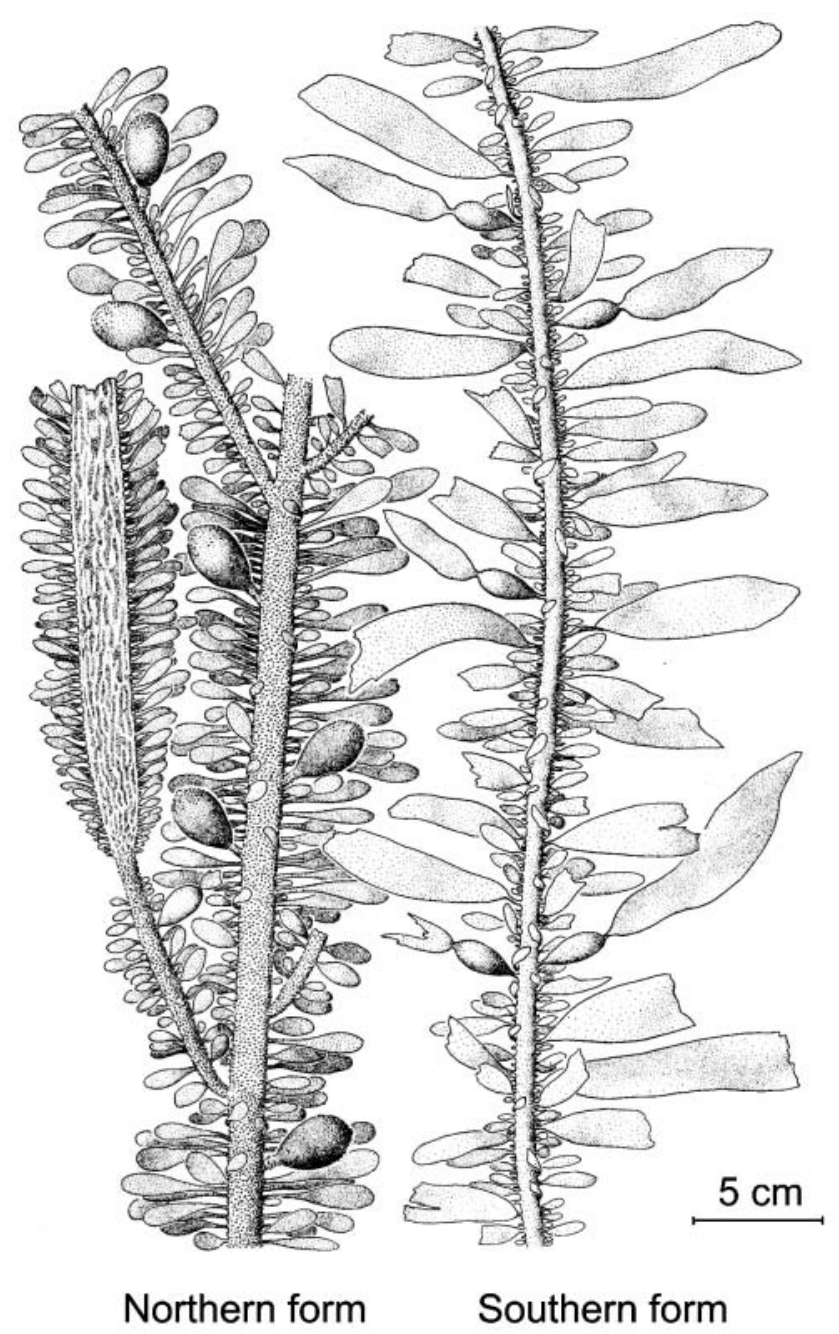

Fig. 1. Egregia menziesii. Examples of 2 different morphologies (from Abbott \& Hollenberg [1976] with permission of Stanford University Press) 
southern California to Baja California, with plants intermediate to E. laevigata and E. menziesii occurring from Carmel, California, to Baja California and in the Channel Islands. Silva (1957) and Smith (1969) placed the southern limit of E. menziesii at PC, while Hollenberg \& Nicholson (1969) described the southern limit of E. menziesii as northern California, with populations intermediate to E. laevigata and E. menziesii from Carmel, California, to Baja California and the Channel Islands. The most recent taxonomic description (Abbott \& Hollenberg 1976) considers all species of Egregia to be E. menziesii.

In this study we describe 2 geographically distinct morphological forms of Egregia menziesii. We classify as northern-form E. menziesii, those plants with a morphology typical of that described for E. menziesii (Silva 1957). Northern-form E. menziesii have a relatively tough rachis covered with protuberances (tubercles). The thallus is highly branched, and the blades of older fronds are highly dissected (Fig. 1). We classify as southern-form E. menziesii, those plants with a morphology similar to that described for E. laevigata (Silva 1957). Southern-form E. menziesii have a smooth rachis and blades that are larger, elliptical, smoother and more widely spaced than northern $E$. menziesii (Fig. 1). Our observations and previously documented species descriptions suggest that both plant size and morphology are well correlated with geographic location (Silva 1957, Hollenberg \& Nicholson 1969, Smith 1969). Large, highlybranched northern-form E. menziesii seemingly dominate the populations at sites north of PC, while southernform plants are most prevalent at sites south of PC (pers. obs.).

\section{MATERIALS AND METHODS}

Study region: physical correlates of morphological variation. The geographic boundary between the 2 forms of Egregia menziesii at PC also marks a well-known division between 2 biogeographically distinct marine provinces - the Californian and Oregonian biogeographic provinces (Valentine 1966, Briggs 1974, Newman 1979, Doyle 1985, Burton 1998). The region is characterized not only by an abrupt change in species composition, but also by a gradient in several characteristics of the physical environment. Point Conception marks the boundary between 2 regions with very different circulation patterns. In the northern region, coastal winds almost always favor upwelling, but are more variable in winter due to storms (Hendershott \& Winant 1996, Harms \& Winant 1998). The consistently strong coastal upwelling in the northern region brings cold, nutrient-rich waters to the surface, resulting in both cold sea-surface temperatures along the coast and high nutrient concentrations.

Temperature is the most notable and often studied physical difference between these 2 regions (Valentine 1966). The temperature shift at PC is on the order of $4^{\circ} \mathrm{C}$ with warmer waters occurring to the south and cold waters driven by coastal upwelling occurring to the north. We have been continuously recording seawater temperature at several coastal sites north and south of PC since the summer of 1997 using temperature dataloggers (Optic stowaway, Onset Technologies). These data show consistently higher monthly mean temperatures at all sites south of PC at all times of year (Fig. 2).

The temperature gradient is well correlated with a gradient in seawater nutrients (nitrate and nitrite) around PC. Although nutrients are relatively abundant north of PC throughout the year due to the consistent upwelling, seawater nutrient concentrations are considerably lower south of PC. Seawater concentrations of nitrate and nitrite were measured from surf-zone seawater samples collected bimonthly at a variety of

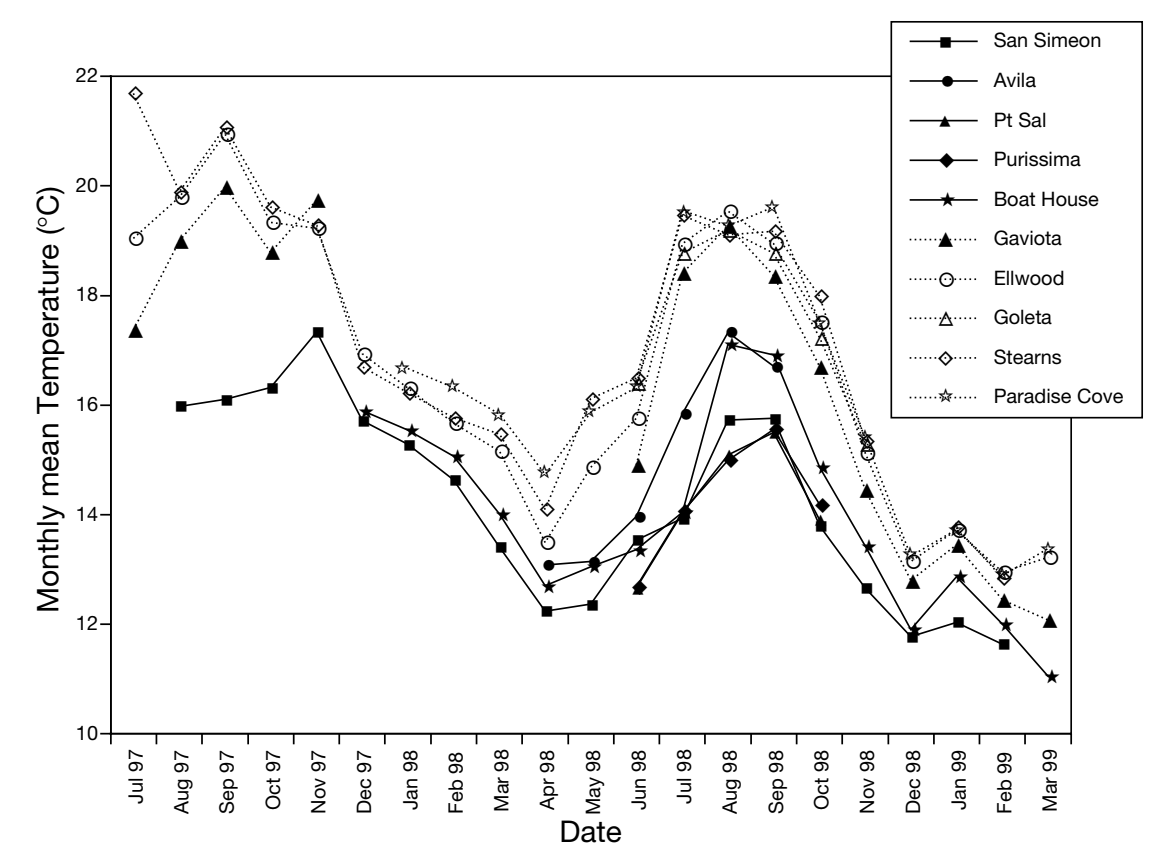

Fig. 2. Monthly mean temperatures from dataloggers attached to pier pilings 1 to $3 \mathrm{~m}$ below MLLW. Sites in key are arranged from north to south. San Simeon pier is within $10 \mathrm{~km}$ of Piedras Blancas, and Paradise Cove pier is within $10 \mathrm{~km}$ of Point Mugu. Continuous lines: sites north of Pont Conception (PC); dashed lines: sites south of PC 


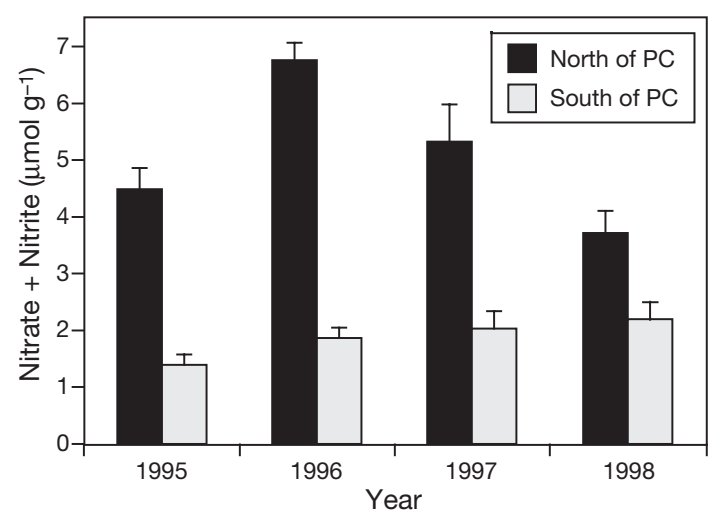

Fig. 3. Mean concentrations of nitrate and nitrite in surf-zone seawater samples taken bimonthly from a variety of sites north and south of PC over a 4 yr period. Data are yearly means $( \pm 1 \mathrm{SE})$

coastal sites both north and south of PC. These data show consistently higher nutrient concentrations at all sites north of PC (Fig. 3).

In addition to temperature and nutrient concentrations, a steep gradient in wave exposure occurs around PC due to a change in orientation of the coastline from predominantly north/south to the north of PC to east/west to the south of PC. Sites north of PC are fully exposed to large ocean swells and storms generated in the North Pacific, whereas sites to the south of PC are more protected from heavy wave action (O'Reilly \& Guza 1993). This gradient in exposure is evident in wave heights recorded from buoys spanning the coast from Big Sur to Los Angeles (Fig. 4).

The abrupt transition in the physical environment at PC is intriguing in the light of the coincident boundary between morphologically distinct forms of Egregia menziesii. Each of these physical characteristics (temperature, nutrient concentration and wave action) has the potential to influence algal growth and performance through its interaction with algal morphology. Here we investigate the ecological advantage of both morphologies in the light of these physical gradients between sites north and south of $\mathrm{PC}$, using reciprocal transplant experiments.

Methods. Morphology: In order to quantify the relative abundances of Egregia menziesii of the 2 different morphological types, we randomly sampled E. menziesii along low-zone intertidal transects at 2 sites north of PC (Piedras Blancas and Cayucos) and 2 sites south of PC (Mussel Shoals and Point Mugu) (Fig. 5) in spring 1997. For each plant we recorded the overall size as the length of the longest stipe, and the number of branches, and scored each plant as 'northern-form' or 'southern-form' based on characteristics of its morphology as described in the preceeding subsection.
Growth and breakage: In spring 1996, we tagged the main rachis of 20 to 25 juvenile E. menziesii at 2 sites south of PC (Alegria and Shoreline) and two sites north of PC (Fields and NVAFB: Fig. 5). We estimated growth of tagged individuals as the change in length of the main rachis using the method of Black (1974). The base of the main rachis on each individual was tagged with a numbered poultry band. We tagged individuals in June 1996 and measured the distance from the holdfast to the intercalary meristematic region of the rachis. In August 1996, we returned to each site and again measured the distance from the holdfast to the meristematic region. Plants were classified as 'broken' if the meristematic region had been broken from the rachis. We were not able to use broken plants to measure growth; however, the proportion of broken plants at a
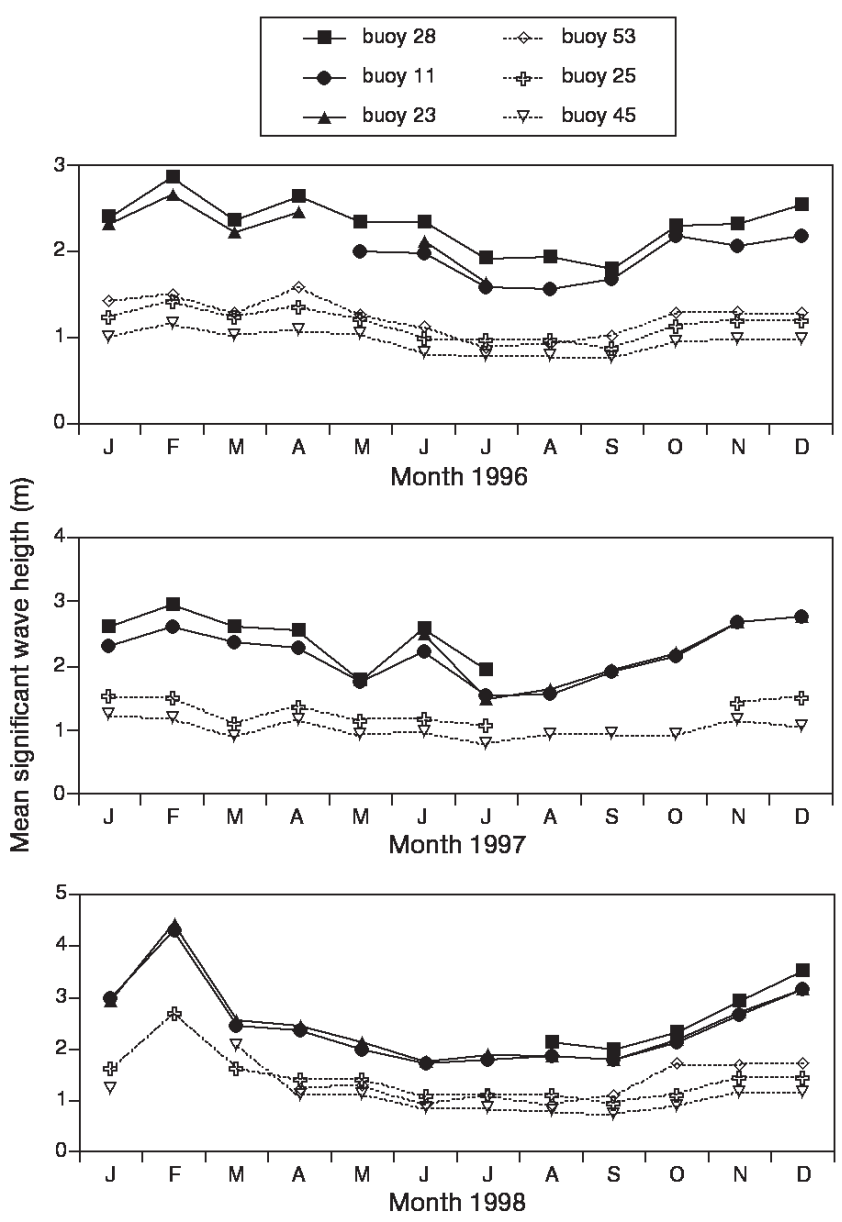

Fig. 4. Monthly mean significant wave height recorded from NOAA buoys spanning the PC boundary (see Fig. 5 for approximate buoy locations). Continuous lines: buoys north of $\mathrm{PC}_{i}$ dashed lines: buoys south of PC (Data from Coastal Data Information Program Scripps Institute of Oceanography) 


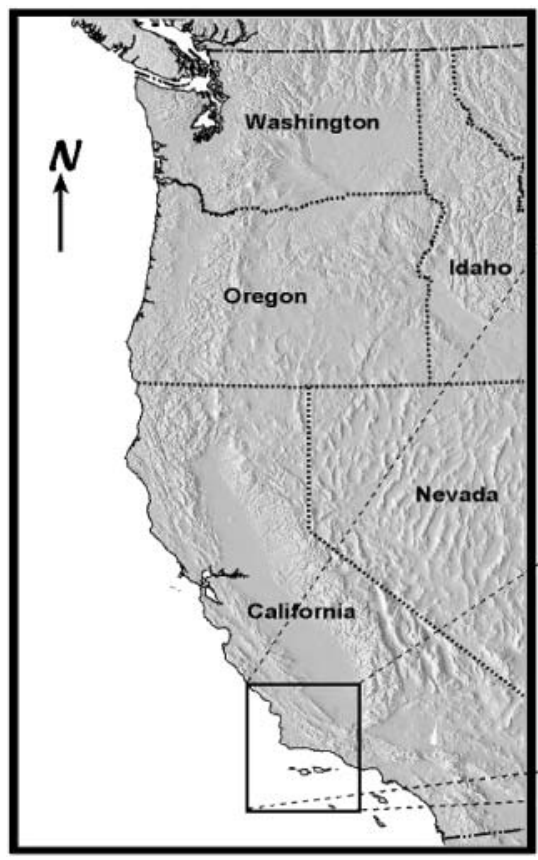

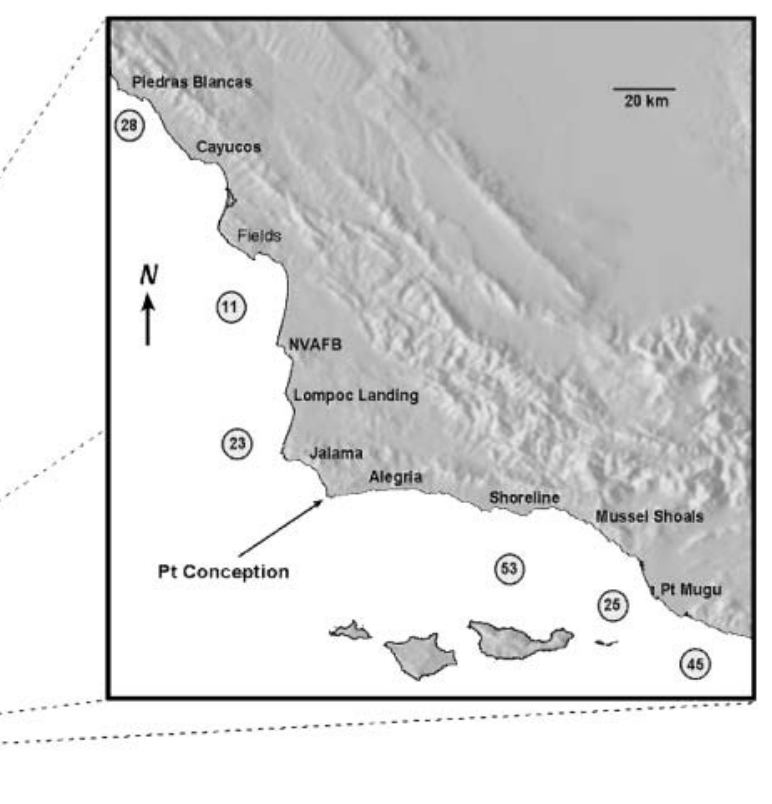

Fig. 5. Map of southern California region showing all sites used in this study and their relative proximity to Point Conception. Encircled numbers: approximate locations of NOAA buoys referred to in Fig. 4 site provides some information on the damage incurred by individuals at that site as a result of wave action relative to plant strength.

Breaking strength and drag: In order to assess the potential for mechanical failure (breakage) for both morphologies of Egregia menziesii, we measured the forces required to break the main rachis and the breaking strengths ([breaking force]/[cross-sectional area of the break]) of northern- and southern-form $E$. menziesii. We measured breaking forces on approximately 30 randomly sampled northern-form E. menziesii at Piedras Blancas and 30 southern-form E. menziesii at Shoreline Beach. The individuals sampled at each site were representative of the range of plant sizes at that site. Plants were lightly clamped to a PVC pipe just below the meristem and wrapped twice around the pipe. A loop of string was tied through the pipe and the other end was attached to the spring scale modified to record maximum force. The spring scale was pulled parallel to the substratum until the stipe broke. For each individual we measured the maximal breaking force and the cross-sectional area of the break.

To measure the hydrodynamic efficiency of each morphological form we measured drag forces for northern- and southern-form Egregia menziesii by towing plants behind a boat at 2, 3 and $4 \mathrm{~m} \mathrm{~s}^{-1}$. We attached a $1 \mathrm{~m}$ section of the main rachis to a spring scale and towed each plant $1 \mathrm{~m}$ under the water's surface while the boat speed increased to 1 of the 3 velocities. For each plant we recorded the force imposed by drag at each velocity.
Transplant experiment. Study sites: We chose 6 intertidal sites for the transplant experiment; 3 were located north of $\mathrm{PC}$, and 3 were located south of PC along the Santa Barbara Channel (Fig. 5). Piedras Blancas $\left(35^{\circ} 40.106^{\prime} \mathrm{N}, 121^{\circ} 17.306^{\prime} \mathrm{E}\right)$ is the northernmost site and the site most exposed to oceanic swells. Juvenile E. menziesii are extremely abundant at this site in spring. Cayucos $\left(35^{\circ} 26.489^{\prime} \mathrm{N}, 120^{\circ} 56.263^{\prime} \mathrm{E}\right)$ is more protected from wave action than Piedras Blancas by a set of offshore rocks. Lompoc Landing $\left(34^{\circ} 43.143^{\prime} \mathrm{N}, 120^{\circ} 36.529^{\prime} \mathrm{E}\right)$ is fully exposed to wave action. Alegria $\left(34^{\circ} 28.030^{\prime} \mathrm{N}, 120^{\circ} 16.674^{\prime} \mathrm{E}\right)$, Mussel Shoals $\left(34^{\circ} 21.315^{\prime} \mathrm{N}, 119^{\circ} 26.547^{\prime} \mathrm{E}\right)$ and Point Mugu $\left(34^{\circ} 03.853^{\prime} \mathrm{N}, 118^{\circ} 59.566^{\prime} \mathrm{E}\right)$ are all south of PC and, in general, more protected from wave action than any of the sites north of PC.

Experimental design: To examine the effects of Egregia menziesii morphology and geographic location (i.e. north vs south of PC) on plant size and survival, we performed a reciprocal transplant experiment using juvenile E. menziesii. We define juveniles as plants consisting of a single blade between 10 and $20 \mathrm{~cm}$ in length. The morphological type of each individual is readily identifiable, even at this young stage. Based on the results of our initial surveys, we collected juvenile E. menziesii for this experiment from Piedras Blancas in the north, where individuals of the northern form are prevalent. We collected southern-form juveniles from 2 sites south of PC (Mussel Shoals and Point Mugu).

At all collection sites, individuals were chosen at random and collected by carefully chiseling out a solid 


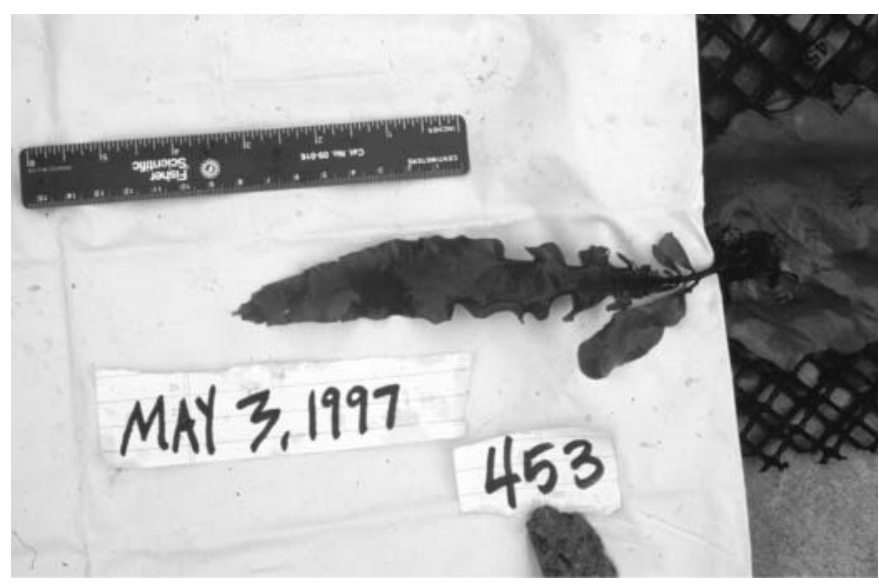

Fig. 6. Egregia menziesii. Photograph of a typical transplant showing attachment of the plant to the vexar mesh and attachment technique

section of the rock from beneath the holdfast. Plants were used in the transplant experiment only if the adhesion of the holdfast to the section of rock remained firm during this process. All plants were placed in a cooler and brought to the Marine Laboratory at the University of California Santa Barbara, and held in flowing seawater for no longer than $3 \mathrm{~d}$ prior to transplantation. The transplant technique involved gluing the sections of rock with attached plants to $20 \times 20 \mathrm{~cm}$ squares of vexar mesh using marine epoxy putty (Kopper's Splash Zone Compound). In this way the plant's attachment to the rock was not altered, and the epoxy did not touch the plant or interfere with its growth (Fig. 6). Each plant was individually marked by attaching a numbered plastic label to the mesh. The squares of mesh with attached plants were secured to the rock at the transplant site using 4 to 8 stainless steel washers, and bolts were placed through the mesh and screwed into plastic wall anchors in the rock.

The experimental design consisted of transplanting 20 to 30 northern- and 20 to 30 southern-form Egregia menziesii to each of 6 transplant sites: 3 north of PC (Piedras Blancas, Cayucos and Lompoc Landing) and 3 south of PC (Alegria, Mussel Shoals and Point Mugu). Unfortunately all the transplants at Piedras Blancas were torn out soon after being transplanted. The transplants were attached at one of the most wave-exposed areas at the site and were all ripped from the rocks during an exceptionally violent El Niño storm. Since there were no plants remaining at the site, Piedras Blancas has been excluded from all analyses.

Data collection: The transplant experiment was initiated in May 1997, when small Egregia menziesii are abundant, and ran through the summer (the period of greatest plant growth) until September 1997. We counted the transplants each month to determine survival over time. In July and near the end of the experiment in August, we measured the size of each individual as maximal projected area. This is the overall 2-dimensional area occupied by a plant when it is fully spread out. This area measurement was calculated by photographing (using either still photos or video) each individual against a white backdrop and subsequently measuring the plant area using an image analysis program (Image 1.41, National Institute of Health). We measured size in terms of area rather than length, since stipe length is not necessarily the best estimate of overall size - many plants are highly branched, and often the longest branches become tattered over time by wave action (Blanchette 1997).

Data analysis: We analyzed the data on the proportional abundance of northern- and southernform Egregia menziesii at different sites and regions using a nominal logistic model. At Piedras and Point Mugu, where the proportions of southern and northern forms were zero, we used a conservative estimate of the total fraction of individuals of a given morphology due to problems with calculating undefined logs of zero to perform the analysis correctly. For Piedras the analysis was performed using a proportion of 0.03 southern/northern forms, and at Point Mugu we used 0.02 northern/southern as opposed to the true observed proportion of zero. Data on stipe length, number of branches and growth rates were analyzed using a nested split-plot mixed-model with region, site nested within region (random factor), and form and region $\times$ form as effects in the model. Growth rate data were $\log$-transformed prior to analysis. Data on frequencies of broken/non-broken stipes were analyzed using a nominal logistic model with sites nested within regions. The effects of plant morphology on breaking force, cross-sectional area and breaking stress were analyzed using analysis of variance. The effects of $E$. menziesii morphology and flow velocity on drag force were analyzed using a repeated-measures MANOVA. Data on survival from the transplant experiment were analyzed using a Kaplan-Meier model of survivorship in each treatment over time. The Kaplan-Meier is a univariate survival model which calculates estimates of survival functions using the product-limit method for groups of right censored data. The data were failure time data, with right censored observations at the end of the study period. Data on proportional change in size were analyzed using a nested split plot mixed model with region, site nested within region (random factor), and form and region $\times$ form as effects in the model. All statistical analyses were performed using JMP statistical software (SAS 1990). 


\section{RESULTS}

\section{Morphology survey}

Results from the Egregia menziesii surveys indicate that plant size and morphology are well correlated with geographic location. The relationship of plant morphologies among sites was also highly significant, with southern-form plants dominating the population at the sites south of PC, and northern-form plants dominating the population at sites north of PC (Fig. 7a, Table 1). Stipe lengths and number of branches were significantly greater at the 2 sites north of PC (Piedras and Cayucos) than at the 2 sites south of PC (Fig. 7b,c, Table 2).

\section{Growth and breakage}

Growth of Egregia menziesii in terms of change in length of the main rachis from June to August 1996 was significantly higher for plants north of PC than for
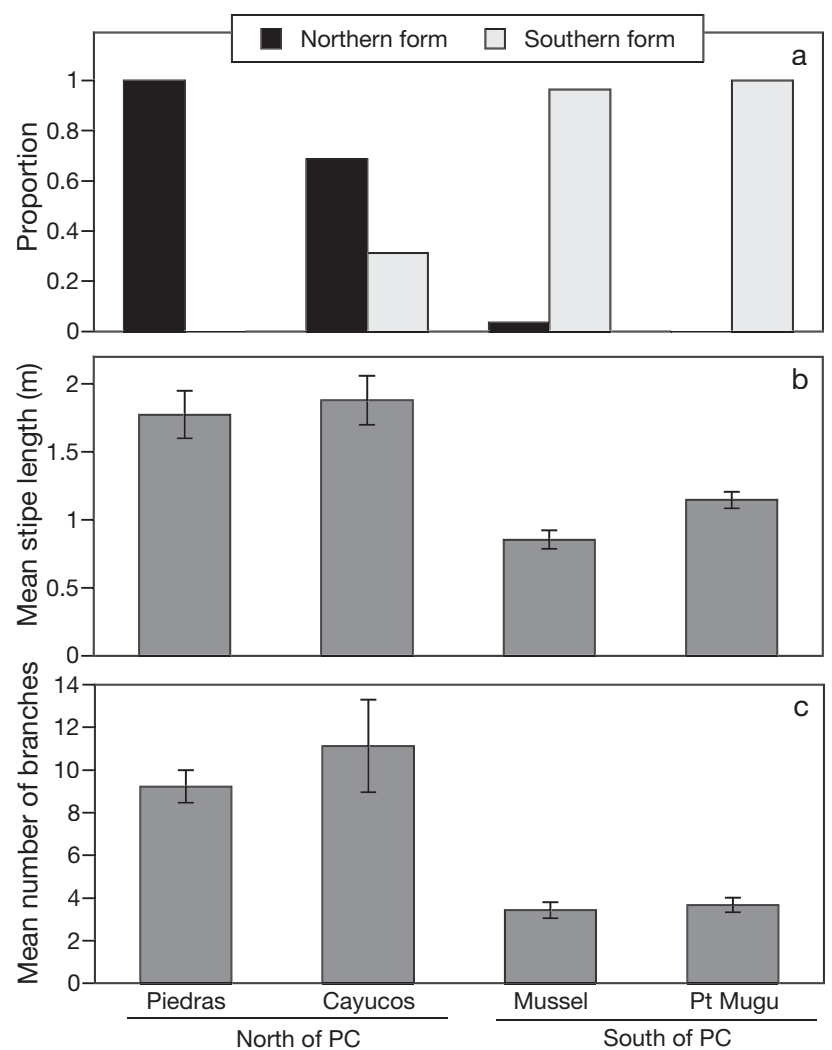

Fig. 7. Egregia menziesii. Results of morphology survey along low-zone intertidal transects at 2 sites north of PC (Piedras Blancas and Cayucos) and 2 sites south of PC (Mussel Shoals and Point Mugu) in spring 1997. (a) Proportion of plants with a 'northern' or 'southern' morphology; (b) mean stipe lengths; (c) mean number of branches
Table 1. Egregia menziesii. Results of nominal logistic model on the influence of geographic location on morphological form. Piedras, Cayucos, Mussel and Point Mugu are all sites (random factors) nested within regions (north and south of Point Conception)

\begin{tabular}{|c|c|c|c|c|}
\hline \multicolumn{5}{|c|}{ Whole Model Test } \\
\hline Model & Log likelihood & $\mathrm{df}$ & $\chi^{2}$ & $\mathrm{p}>\chi^{2}$ \\
\hline Difference & 54.83 & 3 & 109.66 & $<0.0001$ \\
\hline Full & 23.46 & & & \\
\hline Reduced & 78.29 & & & \\
\hline \multicolumn{5}{|c|}{ Effect Wald tests } \\
\hline Source & $\mathrm{df}$ & & Wald $\chi^{2}$ & $\mathrm{p}>\chi^{2}$ \\
\hline Region & 1 & & 25.11 & 0 \\
\hline Site[Region] & 2 & & 5.27 & 0.07 \\
\hline
\end{tabular}

plants south of PC (Fig. 8a, Table 3). Sites north of PC also had a significantly higher proportion of broken plants in 1996 relative to the southern sites (Fig. 8b, Table 4).

\section{Breaking strength and drag}

Northern-form Egregia menziesii were significantly stronger than the southern-form (Fig. 9). On average, southern plants broke at forces that were $45 \%$ lower than those for northern-form plants (Fig. 9a, Table 5). This greater resistance to breaking was not a consequence of differences in stipe size. Cross-sectional areas of the stipes where the breaks occurred were similar (Fig. 9b, Table 5), indicating that material properties of the algae (breaking stress) accounted for the morphology-specific differences in breaking force. Northern forms had significantly higher breaking stresses than the southern forms (Fig. 9c, Table 5).

Northern-forms were not only stronger than southern-forms, but they experienced lower drag forces than southern plants for a given length of stipe and a given flow speed (Fig. 10, Table 6). All plants experienced greater drag at greater flow speeds $\left(F_{2,7}=78.94\right.$, $\mathrm{p}<0.0001)$, and southern-form plants experienced approximately $50 \%$ greater drag than northern-form plants $\left(F_{1,8}=38.64, \mathrm{p}<0.003\right)$ across all flow speeds (flow $\times$ morphology interaction: $F_{2,7}=2.0546, \mathrm{p}=$ 0.1986).

\section{Size and survival}

Plants with the northern morphology had significantly higher survivorship than southern plants at the sites north of PC (Cayucos and Lompoc Landing), whereas plants with the southern morphology had sig- 

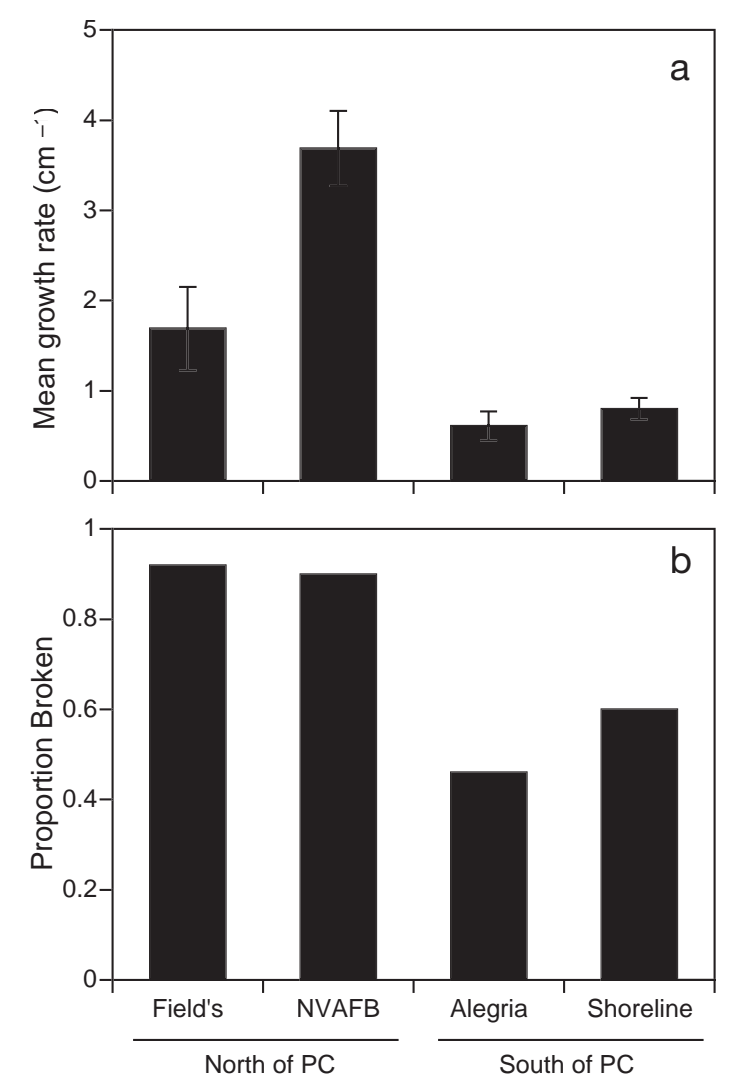

Fig. 8. Egregia menziesii. (a) Mean $( \pm \mathrm{SE})$ change in rachis length per day, and (b) proportion of broken plants north and south of PC

nificantly higher survivorship than northern plants at the sites south of PC (Alegria, Mussel Shoals and Point Mugu) (Fig. 11a; log-rank $x^{2}{ }_{9}=26.96, p<0.001$; Wilcoxon $x^{2}{ }_{10}=21.40, \mathrm{p}<0.011$ ).

A similar interaction between morphology and geographic location was seen in the patterns of size. By August 1997, surviving plants with the northern morphology were larger than southern-morphology plants at the sites north of PC (Cayucos and Lompoc Landing), whereas southern-form plants were larger than northern-form plants at the sites south of PC (Alegria, Mussel Shoals and Point Mugu: Fig. 11b, Table 7).

The differences in total size were net responses to differences in growth rates and damage. To partially separate these influences on algal size, we also compared the size of the largest individuals at each site. Most individuals at the northern sites were broken (especially the southern forms), but a few individuals escaped substantial damage. Comparison of the maximum sizes shows a strikingly different pattern compared to the pattern for averages (Fig. 11c). For both the northern and southern forms, the largest individual was found at Cayucos. By this metric, southern forms
Table 2. Egregia menziesii. Results of a nested ANOVA on the effects of geographic location on mean stipe length and number of branches. Piedras, Cayucos, Mussel and Point Mugu sites (random factors) are nested within regions (north and south of CPoint Conception). df den: df denominator

\begin{tabular}{|c|c|c|c|c|c|}
\hline \multicolumn{6}{|l|}{ Stipe length } \\
\hline Source & df & SS & MS & $F$ & $\mathrm{p}>F$ \\
\hline Model & 3 & 18.101 & 6.034 & 14.876 & $<0.0001$ \\
\hline Error & 116 & 47.05 & 0.40561 & & \\
\hline Source & df & df den & SS & $F$ & $\mathrm{p}>F$ \\
\hline Region & 1 & 2 & 8.962 & 22.097 & 0.042 \\
\hline Site[Region] & 2 & 116 & 0.867 & 1.069 & 0.347 \\
\hline \multicolumn{6}{|c|}{ Number of branches } \\
\hline Source & $\mathrm{df}$ & SS & MS & $F$ & $\mathrm{p}>F$ \\
\hline Model & 3 & 1133.722 & 377.907 & 21.912 & $<0.0001$ \\
\hline Error & 116 & 20000.577 & 17.246 & & \\
\hline Source & df & df den & SS & $F$ & $\mathrm{p}>F$ \\
\hline Region & 1 & 2 & 1133.7217 & 65.737 & 0.015 \\
\hline Site[Region] & 2 & 116 & 0 & 0 & 1 \\
\hline
\end{tabular}
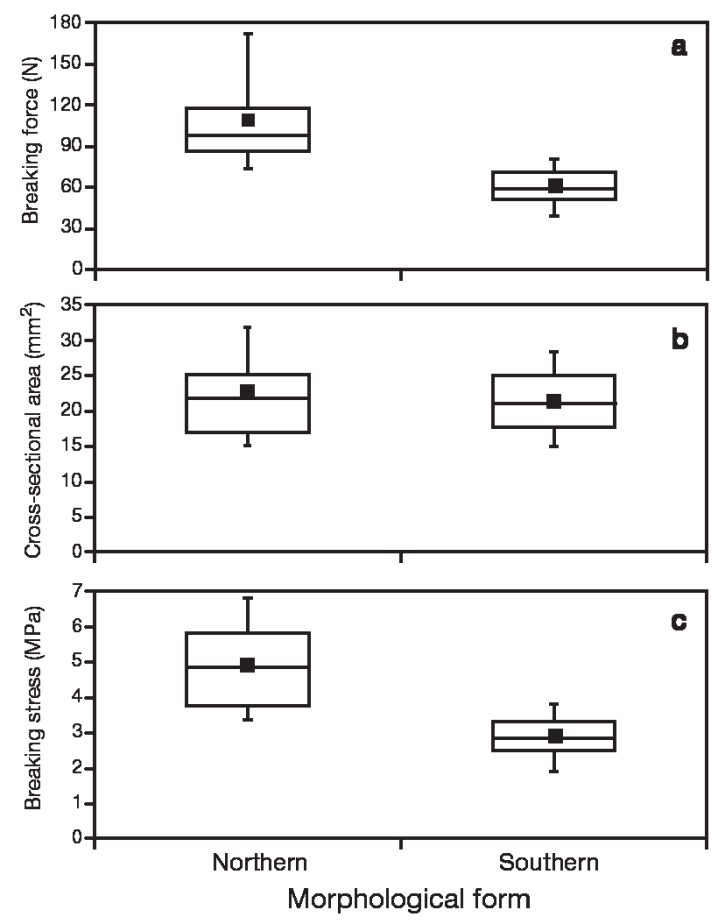

Fig. 9. Egregia menziesii. Box plots of (a) breaking force, (b) cross-sectional area of the broken stipe, and (c) breaking stress (breaking force/cross-sectional area of break) of northern form sampled at a northern site (Piedras Blancas) and southern form sampled at a southern site (Shoreline). Top, bottom and line through middle of boxes correspond to the 75th percentile, 25th percentile and 50th percentiles respectively. Whiskers extend from the 10th percentile (bottom) to the 90th percentile (top); squares designate arithmetic means of the data 


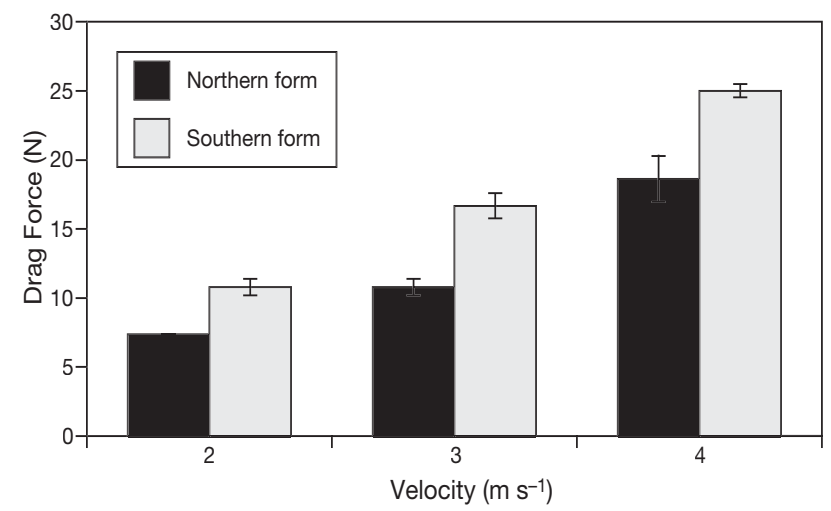

Fig. 10. Egregia menziesii. Drag force (Newtons) measured on $1 \mathrm{~m}$ sections of northern and southern forms at 3 different flow velocities. Data are means $( \pm 1 \mathrm{SE})$
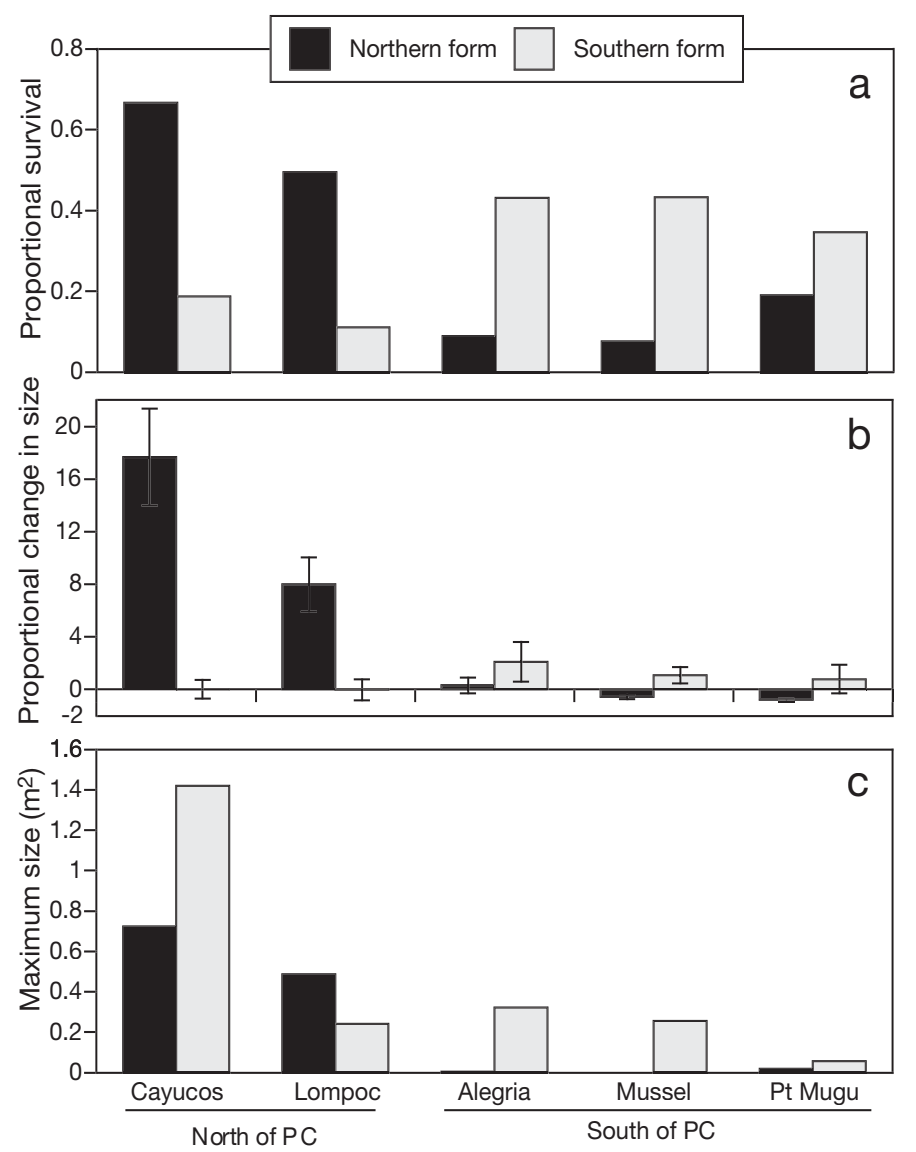

Fig. 11. Egregia menziesii. (a) Proportional survival of northern- and southernform transplants at all transplant sites; (b) mean proportional change in size ([change in size]/[initial size]) of northern- and southern-form transplants at all transplant sites over a 2 mo period. Data are means ( $\pm 1 \mathrm{SE})$ averaged over all plants sampled; (c) maximum size of plants from all treatments in August
Table 3. Egregia menziesii. Repeated-measures ANOVA on the effect of geographic location on mean monthly growth. Field's, NVAFB, Alegria and Shoreline sites (random factors) are nested within regions (north and south of Point Conception). MS num: MS numerator; df num: df numerator

\begin{tabular}{|lccccc|}
\hline Source & df & SS & MS & $F$ & $p>F$ \\
\hline Model & 3 & 19.351 & 6.451 & 17.644 & $<0.0001$ \\
Error & 36 & 13.161 & 0.366 & & \\
Source & SS & MS num & df num & $F$ & $\mathrm{p}>F$ \\
\hline Region & 17.9672 & 17.9672 & 1 & 34.658 & 0.027 \\
Site[Region] & 1.03758 & 0.51879 & 2 & 1.419 & 0.255 \\
\hline
\end{tabular}

did as well or better at northern sites than at their native southern sites. This suggests that southern-morphology E. menziesii have the potential to grow large under northern conditions. Nonetheless, this potential growth advantage in the colder, nutrient-rich waters north of PC was more than offset by increased damage.

\section{DISCUSSION}

Morphological variability within a species is commonly claimed to enhance survival and fitness of plants growing in physically different environments (Gerard et al. 1987, Slatkin 1987, Gerard \& Dubois 1988, Kopczak et al. 1991). In this study, northern-form Egregia menziesii performed best at northern sites than at any of the sites south of PC. Similarly, southernform plants performed best at sites south of PC. The thick, small-bladed, northern-form plants are stronger, experience less drag for a given stipe length and are more resistant to breakage than southern forms. These characteristics are advantageous in the wave-exposed

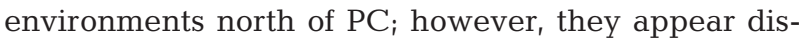
advantageous for rapid growth, particularly in warm,

Table 4. Egregia menziesii. Results of nominal logistic model on the influence of geographic location on stipe breakage. Field's, NVAFB, Alegria and Shoreline sites (random factors) are nested within regions (north and south of Point Conception)

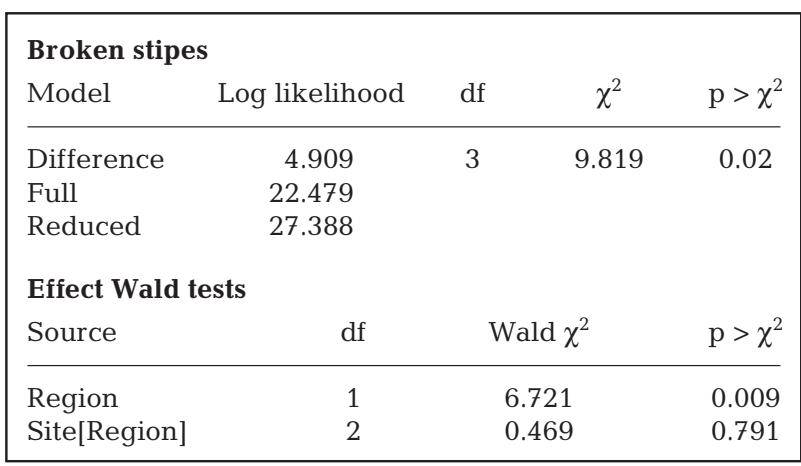


Table 5. Egregia menziesii. Summary of analysis of variance on the effects of morphological form on breaking force, crosssectional area and breaking stress

\begin{tabular}{|lrcccc|}
\hline Source & df & SS & MS & $F$ & $p>F$ \\
\hline Force & & & & & \\
$\quad$ Model & 1 & 348.052 & 348.052 & 41.564 & $<0.0001$ \\
Error & 56 & 468.933 & 8.374 & & \\
\multicolumn{7}{l}{ Cross-sectional area } & & & \\
$\quad \begin{array}{l}\text { Model } \\
\text { Error }\end{array}$ & 56 & $2.65 \mathrm{E}-11$ & $2.65 \mathrm{E}-11$ & 0.706 & 0.404 \\
Stress & & $2.10 \mathrm{E}-09$ & $3.74 \mathrm{E}-11$ & & \\
$\quad$ Model & 1 & 57.88 & 57.879 & 52.311 & $<0.0001$ \\
Error & 56 & 61.962 & 1.106 & & \\
\hline
\end{tabular}

Table 6. Egregia menziesii. Summary of repeated-measures MANOVA on the effects of morphological form and velocity on drag force

\begin{tabular}{|lccccc|}
\hline Parameter & $\begin{array}{c}\text { Wilks' } \\
\text { lambda }\end{array}$ & $F$ & $\begin{array}{c}\text { df } \\
\text { num }\end{array}$ & $\begin{array}{c}\text { df } \\
\text { den }\end{array}$ & p > F \\
\hline Form & 0.172 & 38.641 & 1 & 8 & 0.0003 \\
Velocity & 0.042 & 78.943 & 2 & 7 & $<0.0001$ \\
Form $\times$ Velocity & 0.63 & 2.055 & 2 & 7 & 0.199 \\
\hline
\end{tabular}

nutrient-limited waters. The thin, large-bladed southern-morphology plants seem better designed for nutrient uptake by virtue of enhanced surface area due to large blades, and can grow in warm, low-nutrient waters south of PC where northern forms die. However, southern-form plants are relatively weak and produce high drag, making them especially prone to breakage and loss in high wave-energy environments. Thus there appears to be a tradeoff between morphological traits that maximize growth under low nutrients and traits that minimize breakage in the face of large imposed forces. Given the relative dominance of plants with a particular morphological type in each region and the sharpness of the gradients in the physical environment at PC (wave forces, temperature, and nutrients), plant performance within a region appears to be well correlated with morphology. Thus even within a species, the 'ideal' design (one that maximizes growth and survival in this case) is very much habitat-dependent.

None of the plants in this experiment changed form following the transplant to different locations. Despite large potential gains from a shift in morphology, no such changes occurred. The stereotyped morphology suggests that either the morphological differences are genetically fixed, which prevented phenotypic modification, or that phenotypically plastic responses may have been canalized early in development. We have ongoing studies of transplants of spores from parents with different morphologies to address these alternative explanations.

As noted above, direct measurements of growth in these plants are difficult to make, and changes in total plant size are the net effects of 2 very different processes: growth and breakage. The fact that northernform plants are larger than southern transplants at northern sites and southern-form plants are larger than northern transplants at southern sites (Fig. 11b) appears to be the result of geographic shifts in the differential importance of growth and breakage. To understand the relative importance of plant growth versus breakage in producing the observed pattern, one must determine how the processes contributing to plant growth and breakage may differentially affect northern and southern form plants in both northern and southern regions.

\section{Factors influencing breakage}

Differences in the intensity of wave forces around PC are a likely source of variable success among Egregia menziesii morphotypes. Plant breakage should increase with increasing wave exposure, and breakage is a common occurrence in algae transplanted from protected to exposed areas (Sundene 1964, Gerard \& Mann 1979, Schonbeck \& Norton 1981, DePaula \& DeOliveira 1982, Blanchette 1997). Plants growing in wave-exposed sites are typically tougher and sturdier than those of the same species growing in calmer water (Norton et al. 1982, Blanchette 1997). Furthermore, there is evidence that water motion can influence plant growth at early stages (Kraemer \& Chapman 1991a,b). Cell wall modifications can occur in response to the forces imposed by moving water (Koehl 1986, Armstrong 1987, Sheath \& Hambrook 1988, Kraemer \& Chapman 1991a,b). Kraemer \& Chapman (1991a) have shown that juvenile E. menziesii

Table 7. Egregia menziesii. Repeated-measures ANOVA on the effect of geographic region and site (split-plot design) on proportional change in area of $E$. menziesii in the reciprocal transplant experiment from May to August

\begin{tabular}{|lrrccc|}
\hline Source & df & SS & MS & $F$ & $\mathrm{p}>F$ \\
\hline Model & 6 & 11244.846 & 1874.14 & 5.478 & $<0.0001$ \\
Error & 167 & 57127.075 & 342.08 & & \\
Source & df & df den & SS & $F$ & $\mathrm{p}>F$ \\
\hline Region & 1 & 3 & 1149.123 & 3.359 & 0.164 \\
Site[Region] & 3 & 167 & 1565.144 & 1.525 & 0.209 \\
Form & 1 & 167 & 2565.492 & 7.499 & 0.007 \\
Form $\times$ Region & 1 & 167 & 3735.234 & 10.919 & 0.001 \\
\hline
\end{tabular}


cultured in a high water velocity regime produced blades that were thicker than blades from a low watervelocity regime.

In terms of hydrodynamic performance, the thick, tough stipe of the northern-form Egregia menziesii seems well suited to a wave-exposed environment where thallus breakage may be common. Friedland \& Denny (1995) investigated the mechanisms by which central California E. menziesii could survive extreme hydrodynamic forces typical of a wave-swept intertidal environment. Compared to other common kelp species, they found E. menziesii to have a stipe with high tissue strength and a low drag coefficient, thereby providing a high safety factor in severely wave-swept habitats. Although Friedland \& Denny (1995) did not examine southern-form $E$. menziesii, their finding that northern-form $E$. menziesii is tolerant of extreme wave forces is consistent with our findings that the northern-form E. menziesii is more resistant to breakage (stronger) and produces less drag per unit stipe length than the southern form.

The degree of branching may also be related to the intensity of water motion. It is difficult to say whether a high degree of branching is an adaptation to or a consequence of high wave action. In our study many of the plants transplanted to northern sites, as well as naturally occurring plants at northern sites, were highly branched. The high degree of branching in northern plants may be a result of constant breakage due to wave action. Adventitious branches are produced following physical injury in at least 5 species of brown algae in the family Fucaceae (van Alstyne 1989) and terrestrial plants produce similar outgrowths following injury (Steward 1968).

Based on the greater degree of wave exposure at sites north of $\mathrm{PC}$, we predicted breakage to be higher at all sites north of PC than at southern sites. Data on breakage of naturally occurring tagged Egregia menziesii at a variety of sites north and south of PC (Fig. 8b) support this prediction. Additionally, data from strength distributions of northern and southernform E. menziesii support the prediction that southernform plants are weaker and break at lower forces than northern-form plants. Not only are the southern-form plants weaker, but for a given length they produce greater drag than northern-form plants, effectively increasing the magnitude of force they will experience for a given amount of wave activity. Thus the relatively small proportional increase in size of southern plants in the northern region is probably a result of the high breakage of these morphologically weak plants in a hydrodynamically stressful environment. Breakage is not likely to have an important influence on size in the southern region, where wave forces are much lower and hydrodynamically induced breakage is less prevalent than in the northern region.

\section{Factors influencing growth}

Although high water motion can be disadvantageous to a seaweed with a morphology rendering it susceptible to breakage or dislodgment, some degree of water motion is critical to plant growth and survival. Nutrient availability is extremely important to plant growth in many aquatic systems, and increased water motion has been shown to enhance both nutrient uptake (Parker 1963, Jackson 1977, Wheeler \& North 1980, Norton et al. 1982) and growth (Parker 1963, Norton et al. 1981) in a variety of seaweeds. Hanisak (1983) and Topinka \& Robbins (1976) suggested that in calm-water sites some seaweeds may be under nutrient stress, and the addition of nitrogen has been shown to stimulate seaweed growth in some coastal waters (Chapman \& Craigie 1977, Lapointe \& Tenore 1981).

Geographic variation in seawater nutrient concentrations along the California coast ranges from relatively constant and high nitrate concentrations in Monterey Bay and central California (Bolin \& Abbott 1963, Strub et al. 1987) to oligotrophic conditions found during the summer months in the southern California Bight (Zimmerman \& Kremer 1984, 1986, Zimmerman \& Robertson 1985). Kopczak et al. (1991) found that northern California Macrocystis pyrifera populations (from the Monterey Bay region) were probably never nutrient-limited, whereas summertime nutrient limitation is a common occurrence in the south, at Catalina Island.

Nitrate and nitrite concentrations in seawater samples from sites both north and south of PC (this study) are consistent with the previously described geographic pattern of decreasing nutrient concentrations from north to south. This geographic gradient in nutrient availability matches the corresponding gradient in the growth rate of northern-form Egregia menziesii. Although the southern form also showed a geographical gradient in growth rates (as estimated by the maximum size of transplants), the steepness of the gradient was much less. As a result, southern-form E. menziesii were able to outperform the northern form south of PC, where wave forces are lower and breakage is unlikely. One possible explanation for the relative advantage of the southern form in the low-nutrient conditions of southern sites is that the thin, highly divided, broadleaved thalli may enhance the uptake of essential inorganic nutrients in areas of low flow. Thin-bladed forms of Macrocystis pyrifera found in low-flow environments have been hypothesized to allow enhanced inorganic nitrogen uptake relative to thicker, waveexposed forms (Neushul 1972, Wheeler 1980, Norton et al. 1982). Although experiments by Hurd et al. (1996) suggest that this prediction may not hold true for $M$. integrifolia, the hypothesis warrants testing with 
E. menziesii since the nature of morphological variation in E. menziesii is quite distinct from that in Macrocystis species.

An alternative explanation for the enhanced performance of southern forms in low nutrient conditions may depend more on physiology than morphology per se. If southern-form Egregia menziesii can build up internal nitrogen reserves, they may be able to tolerate periods of low nutrient availability. Nitrate pools do occur in some kelps. The size of the pool seems to fluctuate seasonally with the ambient nitrate concentration and is utilized after ambient nitrate levels decline (Chapman \& Craigie 1977, Chapman et al. 1978, Wheeler \& North 1981). The negative growth rates of northern plants at southern sites with low nutrient concentrations and their high sensitivity to subsaturating nitrate conditions might be expected, because plants at the northern sites rarely experience these conditions. Ecotypic variation in the nutrient utilization response has been shown for Laminaria longicruris (Gagne et al. 1982, Espinoza \& Chapman 1983) and Macrocystis pyrifera (Kopczak et al. 1991). Both are species that span a large geographic range.

In addition to seawater nutrient concentration, temperature may contribute to the differential patterns of algal growth. Although they are often correlated (e.g. cold water tends to be nutrient-rich, while warm water is nutrient-poor), temperature per se has been implicated as a factor limiting algal species distributions (Hutchins 1947, van den Hoek 1982, Yarish et al. 1986, Lüning \& Freshwater 1988, France 1992), and its influence on growth and survival has been well studied. Most North Pacific algal species show high levels of cold tolerance. Lüning \& Freshwater (1988) studied the temperature tolerances of 49 species of benthic macroalgae and seagrasses from Friday Harbor, Washington, and found that all 49 species could survive to $0^{\circ} \mathrm{C}$. However, upper temperature survival limits were variable, and seemed to correspond well with average maxima of summer temperatures at the southern geographical limits of the species. Lüning \& Freshwater found the upper lethal temperature for Egregia menziesii from Washington to be $18^{\circ} \mathrm{C}$. Temperatures south of PC commonly exceed $18^{\circ} \mathrm{C}$ in summer, yet mean temperatures north of PC rarely reach this $18^{\circ} \mathrm{C}$ upper 'lethal limit' (Fig. 2). It would be interesting to examine whether the upper thermal limits of the southern-morphology $E$. menziesii differ from the northern forms. Lüning \& Freshwater acknowledge that there may be local and genetically fixed temperature ecotypes of E. menziesii, since the reported southern boundary of the species is Baja California, where maximum summer temperatures commonly exceed $20^{\circ} \mathrm{C}$. Further evidence for the existence of physiologically distinct ecotypes of $E$. menziesii around PC comes from the work of Chapman
(1962), who found that the 'laevigata' form (southern form) has a photosynthetic optimum at temperatures greater than $15^{\circ} \mathrm{C}$, whereas the 'menziesii' form (northern form) is restricted to areas where ocean temperatures reach $15^{\circ} \mathrm{C}$ for less than 5 mo per year. Although temperature and nutrients are both likely to influence algal growth, it is difficult to separate the individual effects of each of the factors here, since they covary in space and time across the PC boundary.

Based on the cooler temperatures and higher nutrient concentrations at sites north of PC, growth of both forms of Egregia menziesii should be greater at sites north of PC. Data on growth from naturally occurring tagged E. menziesii at a variety of sites north and south of PC (Fig. 8a) provide evidence that growth of native plants is highest north of PC. Additionally, data on the maximum size of E. menziesii from the transplant experiment provide evidence that plants of both forms have the potential to grow extremely large at the northern sites. Northern-form E. menziesii do not seem to grow as large as southern-form E. menziesii at southern sites. The maximal sizes of northern-form plants at all southern sites are lower than the maximal sizes for southern plants (Fig. 11c).

The results of this study suggest that the regionally specific morphological forms of Egregia menziesii in southern California are uniquely adapted for growth and survival under conditions typical of their native region. Direct evidence for genetic differences among these 2 forms of E. menziesii is lacking, but cannot be ruled out. The distribution and relative performance of these distinct forms of E. menziesii has obvious implications for the taxonomy within this genus as well as for our understanding of the factors limiting species' geographical ranges in nature.

Acknowledgements. We thank S. Anghera, T. Jenkins, C. Krenz, and M. Wilson for assistance in the field. Funds for this study were provided by the Mellon Foundation, Department of Energy, Minerals Management Service and the Partnership for Interdisciplinary Studies of Coastal Oceans. This is contribution no. 40 from PISCO, the Partnership for Interdisciplinary Studies of Coastal Oceans: A Long-Term Ecological Consortium funded by the David and Lucile Packard Foundation.

\section{LITERATURE CITED}

Abbott IA, Hollenberg GJ (1976) Marine algae of California. Stanford University Press, Stanford, CA

Anderson EK, North WJ (1966) In situ studies of spore production and dispersal in the giant kelp, Macrocystis. Proc Int Seaweed Symp 5:73-86

Areschoug JE (1876) De tribus Laminarieis et de Spephanocystide osmundacea (Turn.) Trevis. observationes praecursorias. Bot Not 1876:65-73

Armstrong SL (1987) Mechanical properties of the tissues of 
the brown alga Hedophyllum sessile (C. Ag.) Setchelli variability with habitat. J Exp Mar Biol Ecol 114:143-151

Black R (1974) Some biological interactions affecting intertidal populations of the kelp Egregia laevigata. Mar Biol 28:189-198

Blanchette CA (1997) Size and survival of intertidal plants in response to wave action: a case study with Fucus gardneri. Ecology 78:1563-1578

Bolin RL, Abbott DP (1962) Studies on the marine climate and phytoplankton of the central coastal area of California, 1954-1960. Calif Coop Ocean Fish Investig Progr Rep 9: $24-45$

Briggs JC (1974) Marine zoogeography. McGraw-Hill, New York

Burton RS (1998) Intraspecific phylogeography across the Point Conception biogeographic boundary. Evolution 52: 734-745

Chapman ARO (1974) The genetic basis of morphological differentiation in some Laminaria populations. Mar Biol 24: 85-91

Chapman ARO, Craigie JS (1977) Seasonal growth in Laminaria longicruris: relations with dissolved inorganic nutrients and internal reserves of nitrogen. Mar Biol 40: 197-205

Chapman ARO, Markham JW, Lüning K (1978) Effects of nitrate concentration on the growth and physiology of Laminaria saccharina (Phaeophyta) in culture. J Phycol 14: 195-198

Chapman VJ (1962) A contribution to the ecology of Egregia laevigata Setchell. I. Taxonomic status and morphology. Bot Mar 3:33-55

Coyer JA, Olsen JL, Stam WT (1997) Genetic variability and spatial separation in the sea palm kelp Postelsia palmaeformis (Phaeophyceae) as assessed with M13 fingerprints and RAPDs. J Phycol 33:561-568

Dayton PK (1973) Dispersion, dispersal, and persistence of the annual intertidal alga Postelsia palmaeformis Ruprecht. Ecology 54:433-438

DePaula EJ, DeOliveira EC (1982) Wave exposure and ecotypical differentiation in Sargassum cymosum (Phaeophyta-Fucales). Phycologia 21:145-153

Doyle RF (1985) Biogeographical studies of rocky shores near Point Conception, California. PhD thesis, University of California, Santa Barbara, CA

Druehl LD, Harrison PJ, Lloyd KE, Thompson PA (1989) Phenotypic variation in $\mathrm{N}$ uptake by Laminaria groenlandica Rosenvinge (Laminariales, Phaeophyta). J Exp Mar Biol Ecol 127:155-164

Dudgeon SR, Kubler JE, Vadas RL, Davison IR (1995) Physiological responses to environmental variation in intertidal red algae: does thallus morphology matter? Mar Ecol Prog Ser 117:193-206

Espinoza J, Chapman ARO (1983) Ecotypic differentiation of Laminaria longicruris in relation to seawater nitrate concentration. Mar Biol 74:213-218

France R (1992) The North American latitudinal gradient in species richness and geographical range of freshwater crayfish and amphipods. Am Nat 139:342-354

Friedland MT, Denny MW (1995) Surviving hydrodynamic forces in a wave-swept environment: consequences of morphology in the feather boa kelp, Egregia menziesii (Turner). J Exp Mar Biol Ecol 190:109-133

Gagne JA, Mann KH, Chapman ARO (1982) Seasonal patterns of growth and storage in Laminaria longicruris in relation to differing patterns of availability of nitrogen in the water. Mar Biol 69:91-101

Gaines SD, Lubchenco J (1982) A unified approach to marine plant-herbivore interactions. II. Biogeography. Annu Rev Ecol Syst 13:111-138

Gerard VA (1988) Ecotypic differentiation in light-related traits of the kelp Laminaria saccharina. Mar Biol 97:25-36

Gerard VA, DuBois KR (1988) Temperature ecotypes near the southern boundary of the kelp Laminaria saccharina. Mar Biol 97:575-580

Gerard VA, Mann KH (1979) Growth and production of Laminaria longicruris (Phaeophyta) populations exposed to different intensities of water movement. J Phycol 15:33-41

Gerard VA, DuBois K, Greene R (1987) Growth responses of two Laminaria saccharina populations to environmental variation. Hydrobiologia 151/152:229-232

Hanisak MD (1983) The nitrogen relationships of marine macroalgae. In: Carpenter EJ, Capone DG (eds) Nitrogen in the marine environment. Academic Press, New York, p 699-730

Harms S, Winant CD (1998) Characteristic patterns of the circulation in the Santa Barbara Channel. J Geophys Res 103:3041-3065

Harper JL (1977) Population biology of plants. Academic Press, New York

Hendershott MC, Winant CD (1996) Surface circulation in the Santa Barbara Channel. Oceanography (Wash) 9:14-21

Holbrook NM, Putz FE (1989) The influence of neighbors on tree form: effects of lateral shade and prevention of sway on the allometry of Liquidambar styraciflua (sweet gum). Am J Bot 76:1740-1749

Hollenberg G, Nicholson NL (1969) How many species are in the genus Egregia? 50th Meeting of Western Society of Naturalists, Western Society of Naturalists, University of California, Santa Barbara, CA (www.wsa-online.org) (abstract)

Hurd CL, Harrison PJ, Druehl LD (1996) Effect of seawater velocity on inorganic nitrogen uptake by morphologically distinct forms of Macrocystis integrifolia from wavesheltered and exposed sites. Mar Biol 126:205-214

Hutchins LW (1947) The bases for temperature zonation in geographical distribution. Ecol Monogr 17:325-335

Jackson GA (1977) Nutrients and production of giant kelp, Macrocystis pyrifera, off southern California. Limnol Oceanogr 22:979-995

Jaffe M (1973) Thigmomorphogenesis: the response of plant growth and development to mechanical stress. Planta 114: 143-157

Koehl MAR (1986) Seaweeds in moving water: form and mechanical function. In: Givnish T (ed) On the economy of plant form and function, Cambridge University Press, Cambridge, p 603-634

Kopczak CD, Zimmerman RC, Kremer JN (1991) Variation in nitrogen physiology and growth among geographically isolated populations of the giant kelp, Macrocystis pyrifera (Phaeophyta). J Phycol 27:149-158

Kraemer GP, Chapman DJ (1991a) Biomechanics and alginic acid composition during hydrodynamic adaptation by Egregia menziesii (Phaeophyta) juveniles. J Phycol 27: 47-53

Kraemer GP, Chapman DJ (1991b) Effects of tensile force and nutrient availability on carbon uptake and cell wall synthesis in blades of juvenile Egregia menziesii (Turn.) Aresch. (Phaeophyta). J Exp Mar Biol Ecol 149:267-277

Kubler JE, Dudgeon SR (1996) Temperature dependent change in the complexity of form of Chondrus crispus fronds. J Exp Mar Biol Ecol 207:15-24

Lapointe BE, Tenore KR (1981) Experimental outdoor studies with Ulva fasciata Delile. I. Interaction of light and nitrogen on nutrient uptake, growth, and biochemical composition. J Exp Mar Biol Ecol 53:135-152 
Lüning K, Freshwater W (1988) Temperature tolerance of northeast Pacific marine algae. J Phycol 24:310-315

Neushul M (1972) Functional interpretation of benthic marine algal morphology. In: Abbott IA, Kurogi M (eds) Contributions to the systematics of benthic algae in the North Pacific. Japanese Society of Phycology, Tokyo, p 47-71

Newman WA (1979) Californian transition zone: significance of short-range endimics. In: Gray J, Boucot AJ (eds) Historical biogeography, plate tectonics, and the changing environments. Oregon State University Press, Corvallis, OR, p 399-416

Niklas K (1995) Plant biomechanics. University of Chicago Press, Chicago, IL

Norton TA (1991) Conflicting constraints on the form of intertidal algae. Brit Phycol J 26:203-218

Norton TA, Mathieson AC, Neushul M (1981) Morphology and environment. In: Lobban C, Wynne MJ (eds) The biology of seaweeds. University of California Press, Berkeley, CA, p 421-451

Norton TA, Mathieson AC, Neushul M (1982) A review of some aspects of form and function in seaweeds. Bot Mar 25:501-510

O'Reilly WC, Guza RT (1993) A comparison of two spectral wave models in the Southern California bight. Coast Eng 19:263-282

Parker BC (1963) Translocatation in the giant kelp Macrocystis. Science 140:891-892

Pielou E (1978) Latitudinal overlap of seaweed species: evidence for quasi-sympatric speciation. J Biogeogr 5: 227-238

Reed DC, Laur DR, Ebeling AW (1988) Variation in algal dispersal and recruitment: the importance of episodic events. Ecol Monogr 58:321-335

SAS (1990) SAS procedures guide. Version 6. SAS Institute, Cary, NC

Schonbeck MW, Norton TA (1981) Growth forms of Fucus distichus in the San Juan Islands of Washington State. Proc Int Seaweed Symp 8:475-483

Setchell WA (1896) Notes on kelps. Erythea 4:41-48

Sheath RG, Hambrook JA (1988) Mechanical adaptations to flow in freshwater red algae. J Phycol 24:107-111

Silva PC (1957) Notes on Pacific marine algae. Madrono 14: $41-51$

Slatkin M (1987) Gene flow and the geographic structure of natural populations. Science 236:787-792

Smith GM (1969) Marine algae of the Monterey Penninsula,

Editorial responsibility: Kenneth Heck (Contributing Editor), Dauphin Island, Alabama, USA
California. Stanford University Press, Stanford, California Steward FC (1968) Growth and organization in plants. Addison-Wesley, Reading, MA

Strub PT, Allen JS, Huyer A, Smith RL (1987) Seasonal cycles of currents, temperatures, winds and sea level over the northeast Pacific continental shelf: $35 \mathrm{~N}$ to $48 \mathrm{~N}$. J Geophys Res 92:1507-1526

Sundene O (1964) The ecology of Laminaria digitata in Norway in view of transplant experiments. Norw J Bot 11: 83-107

Topinka JA, Robbins JV (1976) Effects of nitrate and ammonium enrichment on growth and nitrogen physiology in Fucus spiralis. Limnol Oceanogr 21:659-664

Valentine JW (1966) Numerical analysis of marine molluscan ranges on the extratropical northeastern Pacific shelf. Limnol Oceanogr 11:198-211

van Alstyne KL (1989) Adventitious branching as a herbivoreinduced defense in the intertidal brown alga Fucus distichus. Mar Ecol Prog Ser 56:169-176

van den Hoek C (1982) The distribution of benthic marine algae in relation to the temperature regulation of their life histories. Biol J Linn Soc 18:81-144

Wheeler PA, North WJ (1980) Effect of nitrogen supply on nitrogen content and growth rate of juvenile Macrocystis pyrifera (Phaeophyta) sporophytes. J Phycol 16:577-582

Wheeler PA, North WJ (1981) Nitrogen supply, tissue composition and frond growth rates for Macrocystis pyrifera off the coast of southern California. Mar Biol 64:59-69

Wheeler WN (1980) Effect of boundary layer transport on the fixation of carbon by the giant kelp Macrocystis pyrifera. Mar Biol 56:103-110

Yarish C, Breeman AM, van den Hoek C (1986) Survival strategies and temperature responses of seaweeds belonging to different biogeographic distribution groups. Bot Mar 24:215-230

Zimmerman RC, Kremer NJ (1984) Episodic nutrient supply to a kelp forest ecosystem in southern California. J Mar Res 42:591-604

Zimmerman RC, Kremer NJ (1986) In situ growth and chemical composition of the giant kelp, Macrocystis pyrifera: response to temporal changes in ambient nutrient availability. Mar Ecol Prog Ser 27:277-285

Zimmerman RC, Robertson DL (1985) Effects of El Niño on local hydrography and growth of the giant kelp, Macrocystis pyrifera, at Santa Catalina Island, California. Limnol Oceanogr 30:1298-1302

Submitted: February 14, 2000; Accepted: January 9, 2002 Proofs received from author(s): August 9, 2002 